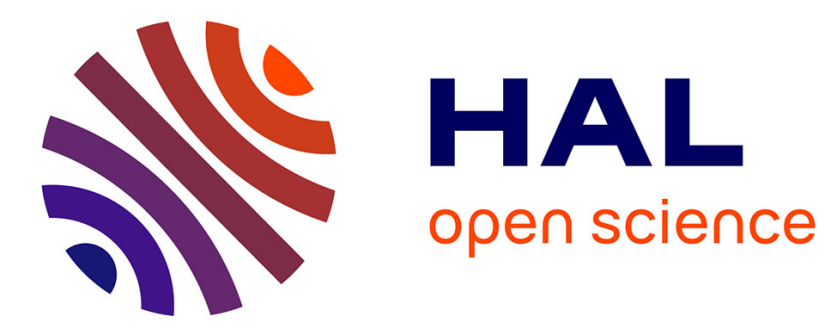

\title{
The Bicyclic Polyselenium Cation Se102+ in the Structure of Se10[Bi4Cl14]
}

\author{
Johannes Beck, Steffen J. Eck
}

\section{To cite this version:}

Johannes Beck, Steffen J. Eck. The Bicyclic Polyselenium Cation Se102+ in the Structure of Se10[Bi4Cl14]. Journal of Inorganic and General Chemistry / Zeitschrift für anorganische und allgemeine Chemie, 2010, 636 (11), pp.1910. 10.1002/zaac.201000165 . hal-00552477

\section{HAL Id: hal-00552477 \\ https://hal.science/hal-00552477}

Submitted on 6 Jan 2011

HAL is a multi-disciplinary open access archive for the deposit and dissemination of scientific research documents, whether they are published or not. The documents may come from teaching and research institutions in France or abroad, or from public or private research centers.
L'archive ouverte pluridisciplinaire HAL, est destinée au dépôt et à la diffusion de documents scientifiques de niveau recherche, publiés ou non, émanant des établissements d'enseignement et de recherche français ou étrangers, des laboratoires publics ou privés. 
The Bicyclic Polyselenium Cation Se102+ in the Structure of Se10[Bi4Cl14]

\begin{tabular}{|r|l|}
\hline Journal: & Zeitschrift für Anorganische und Allgemeine Chemie \\
\hline Manuscript ID: & zaac.201000165.R1 \\
\hline Wiley - Manuscript type: & Communication \\
\hline $\begin{array}{r}\text { Date Submitted by the } \\
\text { Author: }\end{array}$ & 08-May-2010 \\
\hline Complete List of Authors: & $\begin{array}{l}\text { Beck, Johannes; Universität Bonn, Inst. Anorganische Chemie } \\
\text { Eck, Steffen J. }\end{array}$ \\
\hline Keywords: & Selenium, Cluster, Polycation, Chloridobismutate, Crystal Structure \\
\hline \multicolumn{2}{|l}{} \\
\hline
\end{tabular}

\section{s) ScholaroNE" \\ Manuscript Central}




\section{The Bicyclic Polyselenium Cation $\mathrm{Se}_{10}{ }^{2+}$ in the Structure of $\mathrm{Se}_{10}\left[\mathrm{Bi}_{4} \mathrm{Cl}_{14}\right]$}

\section{Johannes Beck* and Steffen J. Eck}

Bonn, Institut für Anorganische Chemie der Universität

Received...............................

*Prof. Dr. J. Beck

Inst. f. Anorg. Chemie d. Universität

Gerhard-Domagk-Str. 1

D-53121 Bonn

e-mail: j.beck@uni-bonn.de 
Keywords: Selenium; Cluster; Polycation; Chloridobismutate; Crystal Structure

\begin{abstract}
In the ternary system $\mathrm{Se} / \mathrm{Bi} / \mathrm{Cl}$ a new polycation containing phase besides the already known $\mathrm{Se}_{4}\left[\mathrm{Bi}_{4} \mathrm{Cl}_{14}\right] \mathrm{Se}_{8}\left[\mathrm{Bi}_{4} \mathrm{Cl}_{14}\right]$, and $\mathrm{Se}_{10}\left[\mathrm{Bi}_{5} \mathrm{Cl}_{17}\right]$ was discovered. Red, transparent, plate shaped crystals of $\mathrm{Se}_{10}\left[\mathrm{Bi}_{4} \mathrm{Cl}_{14}\right]$ were formed by reaction of $\mathrm{Se} / \mathrm{SeCl}_{4} / \mathrm{BiCl}_{3}$ in $15 / 1$ / 8 molar ratio in evacuated glass ampoules applying a temperature gradient from 90 to $80{ }^{\circ} \mathrm{C}$. The crystal structure consists of bicyclic $\mathrm{Se}_{10}{ }^{2+}$ cations and of layered chloridobismutate anions with the cations located between the anionic planes. The atoms of the cation form a six membered ring with a $\mathrm{Se}_{4}$ chain bridging over the 1,4 positions of the $\mathrm{Se}_{6}$ ring. The anions are made up of $\mathrm{BiCl}_{7}$ polyhedra connected via common edges to layers ${ }_{\infty}^{2}\left[\mathrm{Bi}_{4} \mathrm{Cl}_{14}{ }^{2-}\right] . \mathrm{Se}_{4}\left[\mathrm{Bi}_{4} \mathrm{Cl}_{14}\right]$, $\mathrm{Se}_{8}\left[\mathrm{Bi}_{4} \mathrm{Cl}_{14}\right], \mathrm{Se}_{10}\left[\mathrm{Bi}_{4} \mathrm{Cl}_{14}\right]$, and $\mathrm{Te}_{8}\left[\mathrm{Bi}_{4} \mathrm{Cl}_{14}\right]$ all contain an anion of identical formula and two-dimensional connectivity, but these polymeric chloridobismutates are not isostructural. The structural differences are discussed on basis of the different topologies of the nets made up by the Bi atoms.
\end{abstract}




\section{Introduction}

Bismuth trichloride is a strong Lewis acid. It reacts with chloride ion donors under formation of chloridobismutates. $\left[\mathrm{BiCl}_{4}\right]^{-}$is formally the first product, but since $\mathrm{Bi}^{3+}$ ions prefer higher coordination numbers between six and eight, it is generally observed that variable amounts of $\mathrm{BiCl}_{3}$ associate with tetrachloridobismutate under formation of chloridobismutates of higher nuclearity. The weak donor strength of these chloridobismutates is obvious in their ability to stabilize "naked" polycationic clusters of the elements of the chalcogens [1]. In the ternary system $\mathrm{Se} / \mathrm{Bi} / \mathrm{Cl}$ three compounds containing polycationic clusters were already discovered: $\mathrm{Se}_{4}\left[\mathrm{Bi}_{4} \mathrm{Cl}_{14}\right]$, containing the square planar $\mathrm{Se}_{4}{ }^{2+}$ ion [2], $\mathrm{Se}_{8}\left[\mathrm{Bi}_{4} \mathrm{Cl}_{14}\right]$, containing the bicyclic $\mathrm{Se}_{8}{ }^{2+}$ ion [2], and $\mathrm{Se}_{10}\left[\mathrm{Bi}_{5} \mathrm{Cl}_{17}\right]$ with the bicyclic $\mathrm{Se}_{10}{ }^{2+}$ cluster ion [3]. We discovered a fourth phase in this system and report on the synthesis and structure of $\mathrm{Se}_{10}\left[\mathrm{Bi}_{4} \mathrm{Cl}_{14}\right]$.

\section{Experimental}

Bismuth and Selenium were used as commercial products. Bismuth was purified by melting under argon protecting gas and decanting the melt from the black residue. $\mathrm{SeCl}_{4}$ and $\mathrm{BiCl}_{3}$ were prepared by reaction of the elements with $\mathrm{Cl}_{2}$. The chlorine gas was purified by condensing to the liquid state at $-75{ }^{\circ} \mathrm{C}$ in a U-shaped vessel. $\mathrm{The}^{\mathrm{Cl}_{2}}$ gas stream for the chlorination reaction was established by bubbling argon gas through the cold, liquid chlorine. $\mathrm{SeCl}_{4}$ and $\mathrm{BiCl}_{3}$ were both sublimated in the $\mathrm{Cl}_{2} / \mathrm{Ar}$ stream. All further manipulations like charging and opening of the reaction ampoules were performed in an argon filled glove box.

Glass ampoules of $12 \mathrm{~cm}$ length and $1.4 \mathrm{~cm}$ diameter were filled with $\mathrm{Se}, \mathrm{SeCl}_{4}$, and $\mathrm{BiCl}_{3}$ in the molar ratio 15 / 1 / 8 in a total amount of $300 \mathrm{mg}$. The ampoules were evacuated, sealed and placed in a horizontal tube furnace. After keeping at $80{ }^{\circ} \mathrm{C}$ for 4 hours, a temperature gradient 90 to $80{ }^{\circ} \mathrm{C}$ was applied along the ampoule for 36 hours. Besides the main products $\mathrm{Se}_{4}\left[\mathrm{Bi}_{4} \mathrm{Cl}_{14}\right]$ and $\mathrm{Se}_{10}\left[\mathrm{Bi}_{5} \mathrm{Cl}_{17}\right]$, red transparent plate shaped crystals were deposited along the walls of the reaction ampoule.

Crystals were isolated by immersing in cold perfluorinated oil. Diffraction data were recorded with a Bruker Nonius CCD diffractometer at low temperature generated with a cold nitrogen stream. The space group was derived from the reciprocal lattice extinctions as $P 2{ }_{1} 2{ }_{1} 2_{1}$ and the non-centrosymmetry was confirmed during the refinements. The structure was solved by direct methods [4] and refined with anisotropic displacement parameters for all atoms [5]. A Flack $x$ parameter of $-0.042(4)$ showed the absence of inversion twinning [6]. An empirical 
absorption correction was applied to the data [7]. Further crystallographic data for the crystal structure determination have been deposited with the Fachinformationszentrum Karlsruhe under the deposit number CSD-421619 [8]. For the graphical representations the program DiAMOND was used [9].

\section{Results and Discussion}

$\mathrm{Se}_{10}\left[\mathrm{Bi}_{4} \mathrm{Cl}_{14}\right]$ is formed in the reaction of $\mathrm{Se}, \mathrm{SeCl}_{4}$, and $\mathrm{BiCl}_{3}$ besides the related phases $\mathrm{Se}_{4}\left[\mathrm{Bi}_{4} \mathrm{Cl}_{14}\right], \mathrm{Se}_{10}\left[\mathrm{Bi}_{5} \mathrm{Cl}_{17}\right]$ and $\mathrm{Se}_{8}\left[\mathrm{Bi}_{4} \mathrm{Cl}_{14}\right]$. Small differences in the reaction conditions favour the formation of one of the different compounds. For the synthesis of $\mathrm{Se}_{10}\left[\mathrm{Bi}_{4} \mathrm{Cl}_{14}\right]$, the reaction conditions were found to be optimal at a $\mathrm{Se} / \mathrm{SeCl}_{4} / \mathrm{Bi}$ ratio of $15 / 1 / 8$ and a temperature of $90{ }^{\circ} \mathrm{C}$. The crystals are deposited from the gas phase and can be distinguished visually by their thin platy shape from the neighbouring phases.

The crystal structure consists of discrete $\mathrm{Se}_{10}{ }^{2+}$ cations and of polymeric chloridobismutate anions ${ }_{\infty}^{2}\left[\mathrm{Bi}_{4} \mathrm{Cl}_{14}{ }^{2-}\right]$. The cation (Fig. 1) is built of a six-membered ring in boat conformation bearing a $\mathrm{Se}_{4}$ chain bridging over the 1,4 positions of the $\mathrm{Se}_{6}$ ring. The $\mathrm{Se}-\mathrm{Se}$ bonds show the typical separation in short bonds around $2.29 \AA$ at the two-coordinated Se atoms and long bonds around $2.43 \AA$ at the three-coordinated Se atoms. The Se-Se-Se angles are almost equalised in the narrow range between 99.73(4) and 102.68(4) ${ }^{\circ}$. The structure of the cation is thus analogous to the ions found in the structures of $\mathrm{Se}_{10}\left[\mathrm{SbF}_{6}\right]_{2}$ [10], $\mathrm{Se}_{10}\left[\mathrm{AlCl}_{4}\right]_{2}$ [10], $\mathrm{Se}_{10}\left[\mathrm{SO}_{3} \mathrm{~F}\right]_{2}$ [11], and $\mathrm{Se}_{10}\left[\mathrm{Bi}_{5} \mathrm{Cl}_{17}\right]$ [3]. The crystal structure is acentric. Since the structure of the $\mathrm{Se}_{10}{ }^{2+}$ ion allows only for a twofold axis as the only symmetry operation, which is approximately fulfilled in the presented structure, the ion is enantiomorphic.

The $\mathrm{Bi}-\mathrm{Cl}$ bonds in the chloridobismutate anion are spread over a wide range beginning from $2.490(2) \AA(\mathrm{Bi}(1)-\mathrm{Cl}(1))$. A first large gap in the bond lengths is present after $\mathrm{Bi}(3)-\mathrm{Cl}(2)^{\mathrm{IV}}=$ 3.379(2) $\AA$ (Fig. 2). If all $\mathrm{Bi}-\mathrm{Cl}$ distances up to this limit are taken into account, all four independent $\mathrm{Bi}$ atoms obtain coordination polyhedra with coordination number seven. These polyhedra are connected via common edges to layers spread out in the crystallographic $a-b$ plane. The $\mathrm{Se}_{10}{ }^{2+}$ cations are embedded between the layers of the polymeric anions (Fig. 3). 
Four compounds are now known, which all contain the $\left[\mathrm{Bi}_{4} \mathrm{Cl}_{14}\right]^{2-}$ anion, $\mathrm{Se}_{4}\left[\mathrm{Bi}_{4} \mathrm{Cl}_{14}\right]$ $\mathrm{Se}_{8}\left[\mathrm{Bi}_{4} \mathrm{Cl}_{14}\right], \mathrm{Se}_{10}\left[\mathrm{Bi}_{4} \mathrm{Cl}_{14}\right]$, and $\mathrm{Te}_{8}\left[\mathrm{Bi}_{4} \mathrm{Cl}_{14}\right]$ [12]. It is remarkable that the anions in all four structures are not isostructural, despite the identical formula and the shared structural feature of forming two-dimensional arrangements. The differences between the anions, but also their relationship, can be understood if, for simplification, only the arrangement of the Bi atoms is considered. The respective nets of the Bi atoms are depicted in Fig. 4. The nets present in the structures of the selenium containing compounds $\mathrm{Se}_{8}\left[\mathrm{Bi}_{4} \mathrm{Cl}_{14}\right]$ (a), $\mathrm{Se}_{10}\left[\mathrm{Bi}_{4} \mathrm{Cl}_{14}\right]$ (b), and $\mathrm{Se}_{4}\left[\mathrm{Bi}_{4} \mathrm{Cl}_{14}\right]$ (c) are closely related. They show an arrangement of the $\mathrm{Bi}$ atoms analogous to the motif of the oxide ions in the rutile structure. This is in line with the tetragonal symmetry of $\mathrm{Se}_{4}\left[\mathrm{Bi}_{4} \mathrm{Cl}_{14}\right]$ as the representative with the highest symmetry. Orthorhombic $\mathrm{Se}_{10}\left[\mathrm{Bi}_{4} \mathrm{Cl}_{14}\right]$ and triclinic $\mathrm{Se}_{8}\left[\mathrm{Bi}_{4} \mathrm{Cl}_{14}\right]$ are distorted variants. The three nets share the same connection type, expressed by the Schläfli symbol $3^{3} 4^{2}$ [13]. The arrangement of triangles and quadrangles is different in the net belonging to the structure of $\mathrm{Te}_{8}\left[\mathrm{Bi}_{4} \mathrm{Cl}_{14}\right]$ (d), but the connection type $3^{3} 4^{2}$ is also valid for this arrangement.

\section{Acknowledgement}

The authors thank Dr. Jörg Daniels, Inorganic Chemistry Institute of University of Bonn, for encouraging help with the isolation of suitable crystals and for the recording of the diffraction data set. 


\section{References}

[1] J. Beck, Coord. Chem. Rev. 1997, 163, 55-70; S. Brownrigde, I. Krossing, J. Passmore, H. D. B. Jenkins, H. K. Roobottom, Coord. Chem. Rev. 2000, 197, 397-481; J. Beck, Polycationic Clusters of the Heavier Group 15 and 16 Elements, in Inorganic Chemistry in Focus II, G. Meyer, D. Naumann, L. Wesemann (Eds.), Wiley-VCH Publishers, 2005.

[2] J. Beck, T. Hilbert, Z. Anorg. Allg. Chem. 2000, 626, 837-844.

[3] A. Baumann, J. Beck, T. Hilbert, Z. Naturforsch. 1999, 54b, 1253-1259.

[4] G. M. Sheldrick, SHELXS97, Program for Crystal Structure Solution, University of Göttingen, 1997.

[5] G. M. Sheldrick, SHELXL97, Program for Crystal Structure Refinement, University of Göttingen, 1997.

[6] Formula $\mathrm{Bi}_{4} \mathrm{Cl}_{14} \mathrm{Se}_{10}$; orthorhombic; space group $P 2_{1} 2_{1} 2_{1}$; lattice constants $a=$ 11.8457(4), $b=11.9888(4), c=21.9953(7) \AA$; unit cell volume 3123.6(1) $\AA^{3}$; temperature $123(2) \mathrm{K}$; number of formula units $\mathrm{Z}=4$, calculated density $4.512 \mathrm{~g} \mathrm{~cm}^{-3}$; Mo- $K_{\bar{\alpha}}$ radiation $(\lambda$ $=0.71073 \AA$ ) ; crystal dimensions $0.12 \times 0.065 \times 0.006 \mathrm{~mm}^{3}$; range of data collection $5.8 \leq 2 \theta$ $\leq 59.2^{\circ}$; range of indices $h \pm 16, k \pm 16, l \pm 30$; 68190 measured reflections; 8322 independent reflections; $R_{\text {int }}$ for averaging data 0.065 , absorption coefficient $\mu=35.32$ $\mathrm{mm}^{-1} ; 254$ refined parameters, ratio reflections/parameters $=14.6$; reliability factors of refinement $R(|F|)$ for all data $=0.040, R(|F|)$ for $7443\left(F_{\mathrm{o}}\right)>4 \sigma\left(F_{\mathrm{o}}\right)=0.029, w R\left(F^{2}\right)=0.054$; Flack $x$ parameter $-0.042(4)$; max. / min. residual density $+1.61 /-1.80 e \AA^{-3}$.

[7] Z. Otwinowski, W. Minor, Methods in Enzymology: Macromolecular Crystallography 1997, 276 A, 307-326, Eds.: C. W. Carter, Jr. \& R. M. Sweet, Eds., Academic Press.

[8] Detailed crystallographic data can be obtained from the Fachinformationszentrum Karlsruhe, Germany by quoting the deposit number, the names of the authors and the literature citation. Details about inquiries are given on www.fizinformationsdienste.de. 
1 3 4 5 6 7 8

[9] DIAMOND, Molecular and Crystal Structure Visualization Program, Crystal Impact GbR, Bonn, Germany, 2008.

[10] R. C. Burns, W. L. Chan, R. J. Gillespie, W.-C. Luk, J. F. Sawyer, D. R. Slim, Inorg. Chem. 1980, 19, 1432-1439.

[11] M. J. Collins, R. J. Gillespie, J. F. Sawyer, G. J. Schrobilgen, Acta Crystallogr. 1986, C42, 13-16.

[12] J. Beck, A. Stankowski, Z. Naturforsch. 2001, 56b, 453-457.

[13] S. Natarajan, P. Mahata, J. Indian Inst. Sci. 2008, 88, 179-195. 


\section{Legends for Figures}

Fig. 1 The $\mathrm{Se}_{10}{ }^{2+}$ cationic cluster in the structure of $\mathrm{Se}_{10}\left[\mathrm{Bi}_{4} \mathrm{Cl}_{14}\right]$. The thermal ellipsoids represent a probability level of $50 \%$. Bond lengths / $\AA$ : Se(1)-Se(2) 2.421(2), Se(1)-Se(6) 2.423(2), $\operatorname{Se}(1)-\operatorname{Se}(7)$ 2.447(2), $\operatorname{Se}(2)-\operatorname{Se}(3)$ 2.261(2), $\operatorname{Se}(3)-\operatorname{Se}(4)$ 2.457(2), $\operatorname{Se}(4)-\operatorname{Se}(5)$ 2.392(2), $\operatorname{Se}(4)-\operatorname{Se}(10)$ 2.437(2), $\operatorname{Se}(5)-\operatorname{Se}(6)$ 2.269(2), $\operatorname{Se}(7)-\operatorname{Se}(8)$ 2.285(2), Se(8)- $\operatorname{Se}(9)$ 2.361(2), $\operatorname{Se}(9)-\operatorname{Se}(10) 2.277(2)$.

Fig. 2 The four independent $\mathrm{Bi}$ atoms in the structure of $\mathrm{Se}_{10}\left[\mathrm{Bi}_{4} \mathrm{Cl}_{14}\right]$ and their coordination by surrounding $\mathrm{Cl}$ atoms with $\mathrm{Bi}-\mathrm{Cl}$ distances up to $3.4 \AA$. The thermal ellipsoids represent a probability level of $50 \%$. Symmetry operations: $\mathrm{I}=-1 / 2+\mathrm{x},-1 / 2-\mathrm{y},-\mathrm{z} ; \mathrm{II}=-1+\mathrm{x}, \mathrm{y}, \mathrm{z} ; \mathrm{III}=$ $-1 / 2+x, 1 / 2-y,-z ; I V=1+x, y, z ; V=1 / 2+x, 1 / 2-y,-z$. The inset on the bottom shows the distribution of the $\mathrm{Bi}-\mathrm{Cl}$ bond lengths in form of a histogram. The arrow indicates the upper limit of $\mathrm{Bi}-\mathrm{Cl}$ bonds at $3.4 \AA$ taken into account.

Fig. 3 The unit cell of $\mathrm{Se}_{10}\left[\mathrm{Bi}_{4} \mathrm{Cl}_{14}\right]$ in a view along the crystallographic $c$-axis. Shown is one layer of the ${ }_{\infty}^{2}\left[\mathrm{Bi}_{4} \mathrm{Cl}_{14}{ }^{2-}\right]$ anion and the directly neighboured $\mathrm{Se}_{10}{ }^{2+}$ cations. The thermal ellipsoids represent a probability level of $50 \%$.

Fig. 4 The nets of $\mathrm{Bi}$ atoms in a layer of the $\left[\mathrm{Bi}_{4} \mathrm{Cl}_{14}\right]^{2-}$ anions in the structures of $\mathrm{Se}_{8}\left[\mathrm{Bi}_{4} \mathrm{Cl}_{14}\right]$ (a), $\mathrm{Se}_{10}\left[\mathrm{Bi}_{4} \mathrm{Cl}_{14}\right]$ (b), $\mathrm{Se}_{4}\left[\mathrm{Bi}_{4} \mathrm{Cl}_{14}\right]$ (c), $\mathrm{Te}_{8}\left[\mathrm{Bi}_{4} \mathrm{Cl}_{14}\right]$ (d), all in a view perpendicular to the plane of the nets. All $\mathrm{Bi}-\mathrm{Bi}$ distances up to $5.3 \mathrm{~A}$ have been taken into account. The unit cell edges are given with thin lines. The nets are not planar since the height differences of the $\mathrm{Bi}$ atoms perpendicular to the viewing direction amount between 3 and 3.5 $\AA$ A. 


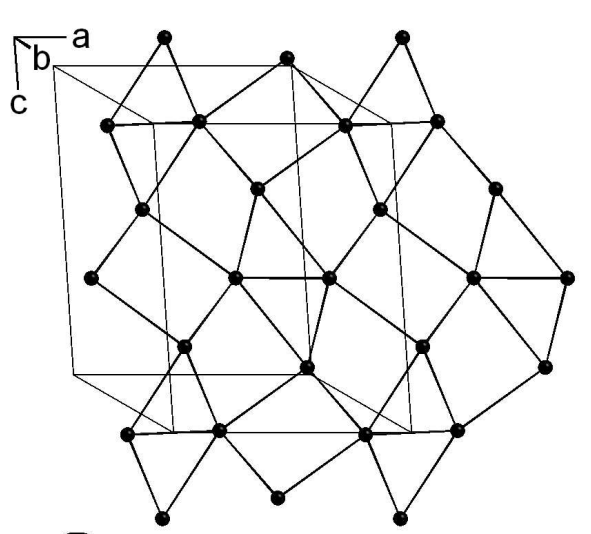

(a)

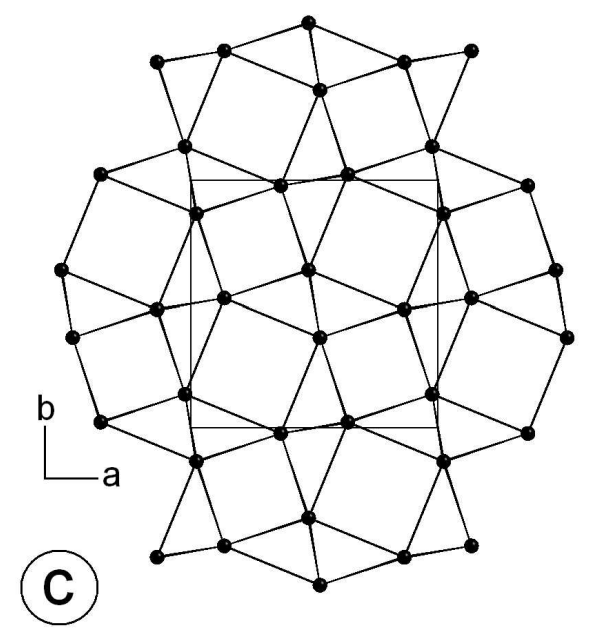

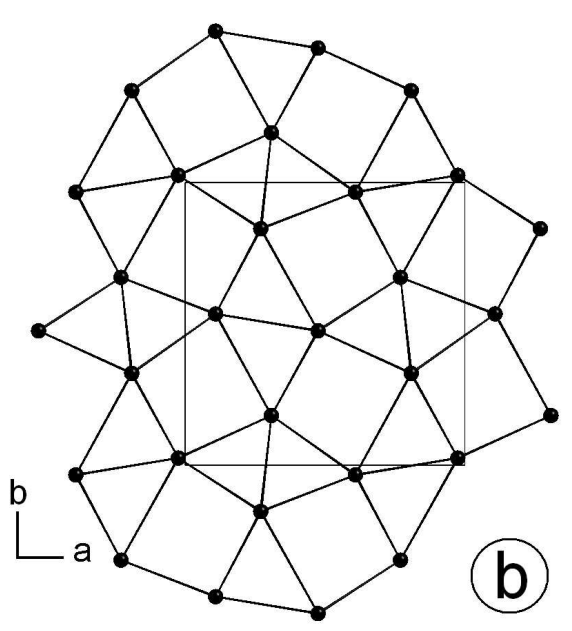

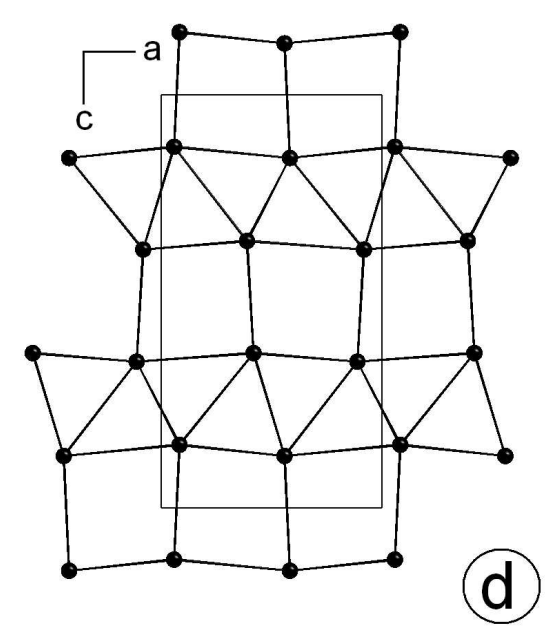




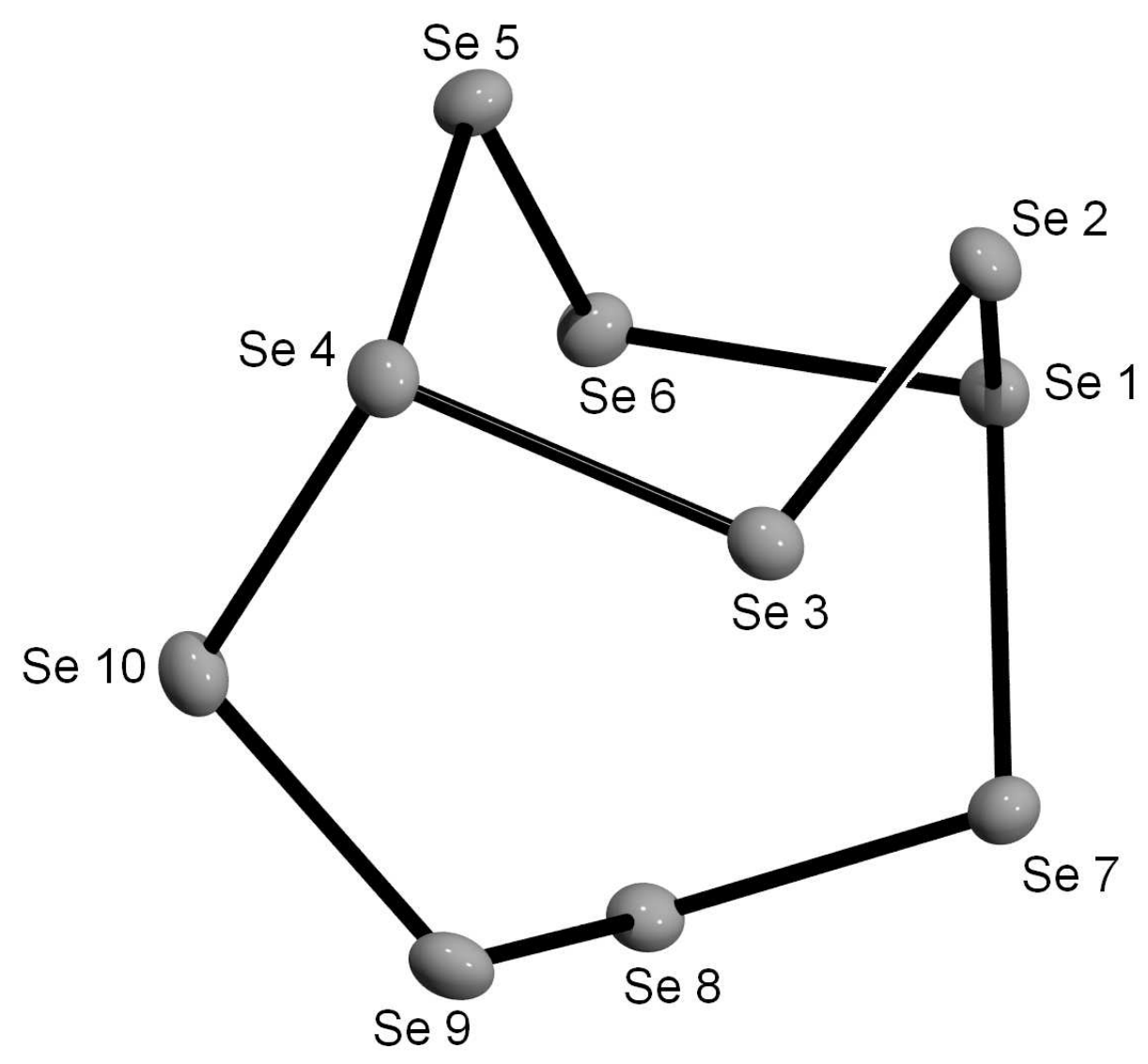



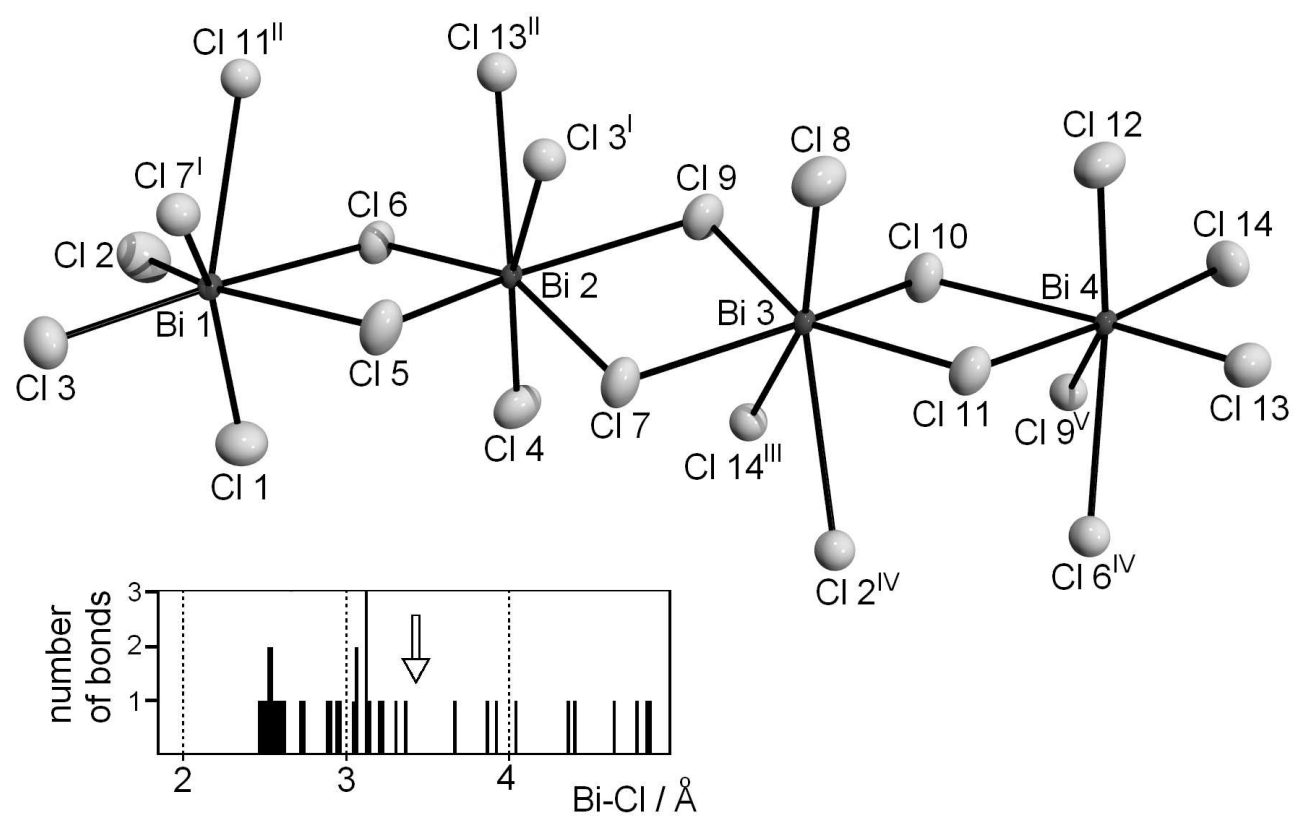


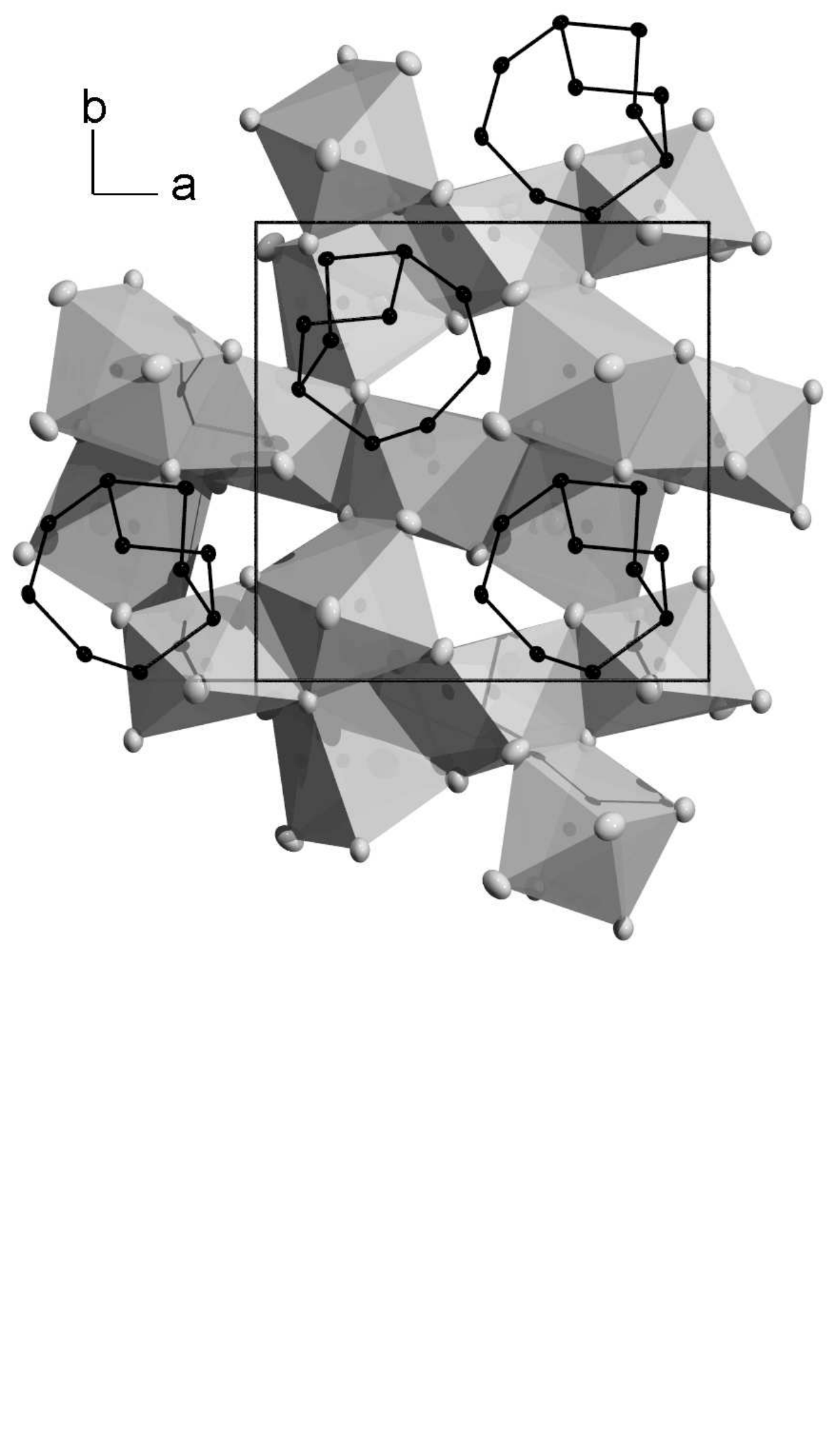

Wiley-VCH 